\title{
SER PROFESSORA, SER MULHER: UM ESTUDO SOBRE CONCEPÇÕES DE GÊNERO E SEXUALIDADE PARA UM GRUPO DE ALUNAS DE PEDAGOGIA
}

\author{
Ana Paula Costa \\ Faculdade de Americana \\ Paulo Rennes Marçal Ribeiro \\ Universidade Estadual Paulista Júlio de Mesquita Filho
}

Resumo: Este trabalho tem por objetivo investigar as concepções de relações de gênero de um grupo de alunas do curso de Pedagogia que já atuam na educação escolar como professoras. Para a realização desta pesquisa qualitativa, de tipologia analítico-descritiva, foi utilizada uma entrevista semiestruturada com as universitárias escolhidas. A construção e a análise do objeto têm como fundamentação teórica os estudos de Michel Foucault, Joan Scott e Guacira Lopes Louro. Constatamos que, em um processo de "acomodação" e "resistência", as categorias "mulher" e "professora" se fundem, o que obscurece, em certa medida, a atuação da professora como profissional da educação.

Palavras-chave: relações de gênero; sexualidade; pedagogia.

\section{Mulher e professora: interseções com o gênero}

Este trabalho tem por objetivo investigar as concepções de relações de gênero de um grupo de alunas do curso de Pedagogia que já atuam na educação escolar como professoras. Autores/as que estudam questões de sexualidade e gênero na escola, discutem e refletem sobre essas questões têm mostrado a importância de trabalhá-las como conteúdo na sala de aula com crianças e adolescentes. ${ }^{1}$ Oficialmente, essa necessidade é corroborada pelos Parâmetros Curriculares Nacionais - PCNs, ${ }^{2}$ que elegem a Orientação

Copyright ( 2011 by Revista Estudos Feministas.

' Por exemplo, Maria Eulina Pessoa CARVALHO e Maria Zuleide da Costa PEREIRA, 2003; Guacira Lopes LOURO,

1997 e 2003; Paulo Rennes Marçal RIBEIRO, 1990; e Paula Regina Costa RIBEIRO, 2003 e 2010.

2 BRASIL, 2000. 
Sexual ${ }^{3}$ como um dos temas transversais que devem ser incorporados aos conteúdos ensinados na instituição escolar.

Partindo, então, do reconhecimento acadêmico de que gênero e sexualidade devem ser objeto de estudo, pesquisa e intervenção na escola, pensamos que também é importante considerar e conhecer a professora que, no contexto escolar, irá lidar com as questões de gênero e sexualidade que surgem na sala de aula. Quem é essa professora? Quais atitudes geralmente tem quando vivencia discriminações de gênero ou manifestações sexuais? Quais os desejos dessa professora?

Mais que "acasos" ou "surpresas" da natureza, relações de gênero e sexualidade são instâncias históricas e culturais. Desse modo, é de suma importância levarmos em consideração a historicidade desses termos, uma vez que vai ser justamente essa característica que permite transformações e mutações no que, fatalmente, fixamos como 'correto' e 'normal' às identidades sexuais e de gênero.

Para Michel Foucault, a sexualidade é um dispositivo histórico, ou seja, uma "invenção social" criada por discursos, normas e instituições que se encontram em determinados tempos e espaços históricos. Em outras palavras, a sexualidade é produzida ao longo da história, sendo, portanto, conceituada como

[...] dispositivo histórico: não a uma realidade subterrânea que se apreende com dificuldades, mas a grande rede de superfície em que a estimulação dos corpos, a intensificação dos prazeres, a incitação do discurso, a formação do conhecimento, o reforço dos controles e das resistências encadeiam-se uns aos outros, segundo algumas grandes estratégias do saber e dos poderes. ${ }^{4}$

Na mesma perspectiva, as relações de gênero se encaixam, pois essa categoria perpassa as concepções, atitudes e práticas referentes ao sexo. Assim, a maneira como nos entendemos como sujeito sexual está entrelaçada com a maneira como também nos entendemos como homens e mulheres, já que, como explica Judith Butler,

o gênero é um modo de existir o próprio corpo, e esse corpo é uma situação, um campo de possibilidades a um tempo recebidas e reinterpretadas, então gênero e sexo parecem ser questões inteiramente culturais.

Podemos observar que essas instâncias, relações de gênero e sexualidade, emergem de nosso cotidiano, como exemplo, a escola. Nesse contexto, pensamos que as concepções que os/as professores/as possuem sobre relações de gênero e, consequentemente, sexualidade fazem parte das relações pedagógicas, ou seja, da forma como conduzem esses assuntos e também como se posicionam sobre esses temas. Assim, utilizando-se de Guacira Lopes Louro, concordamos com a ideia de que

[...] as formas adequadas de fazer, de meninos e meninas, homens e mulheres ajustados/ as aos padrões das comunidades pressupõem uma atenção redobrada sobre aqueles e aquelas que serão seus formadores e formadoras.

\footnotetext{
${ }^{3}$ O tema transversal Orientação Sexual encontra-se no volume 10, juntamente com a Pluralidade Cultural, outro tema que também é enfatizado pelos PCNs. Ao utilizar o termo "Orientação Sexual", estamos remetendonos, como afirma Ribeiro (1990, p. 3-4), a "[...] uma intervenção institucionalizada, sistemática, organizada e localizada, com a participação de profissionais treinados para este trabalho".

${ }^{4}$ Michel FOUCAULT, 1988, p. 100.

${ }^{5}$ Judith BUTLER, 1987, p. 145

${ }^{6}$ LOURO, 2003, p. 106.
} 
Portanto, neste artigo procuramos evidenciar como essas professoras se entendem como mulheres e profissionais da educação, bem como suas concepções sobre o que vêm a ser relações de gênero.

\section{Metodologia}

De abordagem qualitativa, consideramos que esta investigação é do tipo analíticodescritiva, uma vez que "[...] observa, registra, analisa e correlaciona fatos ou fenômenos (variáveis), sem manipulá-los". ${ }^{7}$ Em outras palavras, descreveremos, analisaremos e interpretaremos dados, sem, contudo, interferir na realidade escolhida para este estudo.

Os sujeitos desta pesquisa são as alunas do quarto ano do curso de Pedagogia da Faculdade de Ciências e Letras da Unesp, campus de Araraquara, que já atuam na educação escolar como professoras. A escolha desses sujeitos, alunas que já lecionam, justifica-se pelo fato de que as concepções dos/as professores/as são capazes de subsidiar as concepções de seus/suas alunos/as, já que constituem 'modelos' para os/as educandos/ as. Nesse contexto, torna-se importante conhecer as concepções de relações gênero e sexualidade dessas professoras.

O instrumento de coleta de dados consistiu na realização de uma entrevista semiestruturada com cada aluna/professora, conversa que foi gravada e transcrita. Optamos por esse tipo de entrevista, pois postulamos que é através da fala que podemos conhecer as concepções que norteiam a vida de um indivíduo.

Mediante a abordagem qualitativa, as falas dos sujeitos entrevistados foram analisadas e seus conteúdos agrupados em categorias de análise. A organização dos dados em categorias se fundamentou nos escritos de Laurence Bardin ${ }^{8}$ sobre análise de conteúdo, na modalidade análise temática.

\section{O que é ser mulher?}

Quando indagamos essas professoras sobre "o que é ser mulher?", observamos que suas concepções sobre o sujeito feminino giram em torno do que o conceito de gênero vem nos alertar, ou seja, para as "[...] relações sociais fundadas sobre as diferenças percebidas entre os sexos [...]".

É nesse contexto que ser mulher, para algumas professoras, é ser amorosa, responsável, esposa e mãe, reservada, delicada e romântica:

Para mim, ser mulher é assim, eu acho que eu trocaria de sexo por nada tá. Eu acho que é é muita responsabilidade, mas assim acima de tudo, não sei, muito amor por tudo que eu faço né. Na minha concepção, assim me entregar de corpo e alma em tudo que eu faço, nos relacionamentos, na minha família [...]. (Luísa)

Ser mulher para mim, ai em primeiro lugar é ser mãe né. Eu penso poder casar, vestido de noiva e tal, um sonho, ann, que mais? Hoje, trabalhar, ter minha independência financeira, o que eu penso no momento e, acho que é isso. Você, você se realizar profissionalmente, pessoalmente. (Mariana)

Ser mulher é falar baixo, é pintar o olho, passar batom é, colocar uma pulseira, é ser delicada e carinhosa, hum ser inteligente. Ser mulher é ser sobrevivente né. É acho que, não consigo pensar mais coisas, tô muito no cisco né, na matéria (risos). É, gosto

\footnotetext{
${ }^{7}$ Amado Luiz CERVO e Pedro Alcino BERVIAN, 1996, p. 49.

${ }^{8}$ Laurence BARDIN, 1977.

9 Joan SCOT, 1995, p. 14.
} 
muito de ler algumas coisas sobre mulheres, eu gosto muito da Danuza Leão, das crônicas que ela faz. É, ela sempre deixa a gente muito bem né porque a mulher sempre vence no final (risos). Eu gosto muito dela. Eu gosto de me identificar nela, com as coisas que ela fala né. Ela tem uma visão romântica, mas forte da mulher né, do aspecto frágil né. (Carmem)

Ah, eu acho mais fácil falar em características forte, delicada, romântica, trabalhadora [pausa]. Acho que mais assim, difícil, difícil formular um conceito. (Michele)

A construção do gênero feminino pelos aparatos da biologia gera atributos imutáveis ao sujeito feminino; afinal, a ideia que prevalece é de que a mulher já nasce com essas características. A fala de Luísa afirma bem essa ideia:

Nós [mulheres] sempre temos assim, eu não sei, mas aquela responsabilidade com a casa, com os filhos né. $E$ isso, eu acho que a mulher já nasce predeterminada, não sei se predeterminada né, mas assim pelo que eu conheço, pelo que eu sei, ela já nasce com isso, é de cuidar, de tudo. (Luísa)

No entanto, apesar da relativa "acomodação", "resistências" ao que concerne ser mulher ${ }^{10}$ igualmente podem ser visualizadas nas falas dessas professoras, o que remete à ideia de que ser mulher ultrapassa o que Ihe é "biologicamente determinado". Desse modo, mesmo admitindo à mulher uma essência feminina, esses sujeitos acabam subvertendo a norma, quando, por exemplo, Mariana aponta independência financeira e realização profissional como quesito para o ser mulher; quando Carmem admira o romantismo, mas também a força da mulher em uma crônica; ou quando Michele, dentre várias características, atribui força ao sujeito feminino. Portanto, o que percebemos é que "[...] a aceitação completa de atitudes e comportamentos apropriados aos papéis sexuais (tanto quanto a completa rejeição) é, de fato, bastante rara". "1

Jean Anyon, ao escrever sobre "acomodação" e "resistência" de mulheres e meninas, explica que a apropriação da feminilidade pelo sujeito que nasce com uma vulva não constitui um processo de aceitação incondicional, já que também expressa certa rejeição aos imperativos estipulados pela sociedade ao que deva ser uma mulher. As definições de Ana, Júlia e Mônica do que é ser mulher evidenciam, em um primeiro momento, fortes resistências e, em seguida, momentos de acomodações:

Ser mulher é uma dádiva de Deus, é um dom porque não é fácil. Antes as pessoas falavam da dupla jornada porque a mulher tem que cuidar da casa, dos filhos e ainda trabalhar. Eu acredito que tem até a tripla jornada porque eu tenho que trabalhar, cuidar da minha casa, porque minha mãe também trabalha. Então, eu que resolvo tudo na minha casa, então é difícil. A mulher ainda é vista com um pouco de preconceito e sexo frágil não tem nada. Se fosse uma pessoa frágil não tinha chegado onde chegou, ocupando ocupações em que homens já ocupavam, que sempre foi de homens. (Ana)

O que é ser mulher? Aí, não sei, tanta coisa, é uma coisa assim tão complexa. É, bom, primeiro acho que assim você já tem é, agora não sei se tanto, posso tá falando besteira, mas é tem as diferenças, eu acho que isso existe ainda, aquela diferença de "Ai o homem pode, isso pode, a mulher não pode". Eu acho que isso talvez seja a parte ruim. Então, assim você, ser mulher tem que saber lidar com isso, é saber lidar com todas é as suas limitações, que a sociedade acha que você tem sabe? Isso é

\footnotetext{
10 Jean ANYON, 1990.

11 ANYON, 1990, p. 14.
} 
complicado, saber desviar e lidar com tudo isso é complicado e acho que toda mulher acaba tendo que saber fazer né, acaba tendo que saber fazer isso [...]. (Júlia)

Eu acho que hoje a visão de mulher mudou muito em relação ao que já foi o papel de ser mulher né. Hoje, ser mulher já não significa mais a mulher ser submissa ao lar, aos filhos e à família né? Hoje a mulher tem um espaço de trabalho, um espaço de estudo, um espaço de família. E ann, não sei, acho que esse é o caminho porque a mulher tem mesmo os mesmos direitos que os homens, em relação a tudo né, ao estudo, ao trabalho, a gerar as coisas, a administrar os bens, a casa, a família, da mesma maneira que o homem. Com a diferença que ainda para a mulher, ela, por mais que o homem saia de casa para trabalhar, a mulher sai de casa para trabalhar e ainda tem o serviço de casa né. Mesmo que ela tenha alguém que faça, como empregada doméstica, mas quem acaba administrando a ordem da casa é a mulher né. Então, acho que hoje o, o espaço dela aumentou, o trabalho dobrou né. Porque antes ela tinha só a organização da casa, hoje ela tem a organização da casa e tudo mais que ela quiser conseguir. Mas, eu acho que a mulher em si é mais forte que o homem para muitas coisas, assim em relação aos sentimentos, parece que não, mas eu acho que sim. Em relação a lidar com as coisas, como notícia de doença, ou então, alguma situação difícil que esteja acontecendo. Acho que a mulher tem mais pulso assim, mais determinação para fazer as coisas que o homem. (Mônica)

Notamos que, para essas professoras, ser mulher ultrapassa os limites estipulados pela feminilidade, já que identificamos em suas falas questionamentos quanto às imposições sociais que, muitas vezes, definem os sujeitos femininos, como a ideia de que mulher é o "sexo frágil", ou então, "saber lidar com [...] as limitações [...] que a sociedade acha que você tem".

Porém, essa resistência entra em conformidade com a acomodação quando recaem no imperativo social que legitima e justifica a atuação feminina em sua constituição biológica. Subentende-se, portanto, que ser mulher, como afirma Ana, "é um dom", sendo a palavra "dom", em seu significado no dicionário Larousse Cultural e também no imaginário popular, "dote natural, habilidade, capacidade". ${ }^{22}$

A biologização da concepção de mulher também pode ser encontrada na fala de Mônica. Primeiro, quando essa professora, por mais que reconheça direitos iguais a homens e mulheres, não justifica o porquê de a mulher também ser a responsável pelo serviço de casa, além do trabalho que exerce fora de casa, ou seja, na esfera pública. E, segundo, quando admite, sem explicações detalhadas, uma força interior do sujeito feminino no manejo de situações de vida difíceis.

Esses processos de "acomodação" e "resistência" demonstram como ser mulher é uma construção social que nunca finda. Essa ideia contraria concepções como a de "dom" e de "essência", uma vez que nega o inatismo de características atribuídas a homens e mulheres e recorre aos processos sociais e históricos para explicar a constituição dos gêneros masculino e feminino.

O próprio entendimento de "dom" como algo inato pode ser desconstruído em relação à constituição de masculinidades e feminilidades se pensarmos na mesma linha de raciocínio de Judith Butler, ${ }^{13}$ a qual ratifica que, mesmo antes do nascimento do sujeito, a estipulação de normas e condutas para os gêneros já é posta. Nesse sentido, como alimentar as ideias de que ser mulher é um "dom", ou então, de que a mulher possui uma

\footnotetext{
${ }^{12}$ Elena LOVISOLO, 1992, p. 376.

13 BUTLER, 1987.
} 
força interior se o sujeito já nasce impregnado de construtos sociais, os quais são interpretados e modificados por ele ao longo de sua vida?

Além disso, a ideia de "dom" se dilui quando observamos que a formulação do que é ser mulher é construída por essas professoras por meio do convívio que tiveram com outras mulheres, como a mãe, as avós, irmãs, tias, primas e professoras, além de experiências que tiveram no âmbito familiar, profissional e acadêmico. Desse modo, podemos afirmar que a convivência que essas professoras tiveram com outros sujeitos e com as instituições sociais sinaliza aprendizagens vinculadas a sua constituição como mulheres.

Eu acho que, principalmente, pela minha criação, porque além de ser criada com a mãe, minha "vó" [avó] sempre esteve muito presente. Então, eu acho que a participação delas assim foi fundamental. A minha mãe é, eu acho, muito batalhadora sabe. Eu acho que não é para qualquer homem passar por tudo o que ela já passou, ser mãe adolescente né, que ela também foi mãe aos 15 anos, e passar por tudo que passou e tá firme ainda, sabe sonhadora, batalhadora mesmo [...]. (Luísa)

A, a minha mãe já foi para mim um exemplo de força, é de, uma pessoa forte assim, determinada. Já foi, de uma pessoa honesta, de estar trabalhando, de aguentar o que vier aguentar, porque não é fácil né. (Ana)

Eu tenho, tenho uma, a minha, a minha professora de piano a pessoa que eu admiro, que foi minha professora, que é uma pessoa assim que eu admiro bastante assim não só na parte profissional, mas como pessoa, pelo que ela é sabe, como pessoa. Profissionalmente, também claro, que ela também passou por várias dificuldades e conseguiu chegar onde ela queria. Mas, como pessoa assim, como a forma dela ser, pessoa que eu admiro e vou levar comigo assim com muito carinho. (Júlia)

Concepção? Acho, acredito da, assim, da minha família mesmo, sabe. (Mariana)

Minha mãe é um exemplo muito forte para mim como mulher, como pessoa. $E$ em relação assim às outras coisas, acho que tudo o que a gente vê, mesmo pessoas que eu conheço que conseguem conciliar trabalho com casa, com família, com outras atividades [inaudível]. (Mônica)

É, eu acredito que toda essa minha vivência, minha aprendizagem de vida, de academia é que me foram dando base e construindo essa minha concepção aos poucos, né. Os exemplos que a gente vê, ouve, né. Lê sobre, que são tantos né. Você vai reunindo, pegando um pouco de cada um, formando o quebra-cabeça né, tudo, a vivência, a vivência, né? (Carmem)

Ah, baseado? Acho que nas mulheres que eu conheço né, eu, as mulheres que eu conheço, características incomuns de cada uma. (Michele)

Devemos levar em conta que certas características, como ser amorosa, responsável, esposa e mãe, reservada, delicada e romântica, presentes na fala desses sujeitos em atribuição à constituição da concepção do que é ser mulher também são perpassadas pela religiosidade dessas professoras. Em outras palavras, a crença em Deus e nos postulados da instituição religiosa, seja essa qual for, contribui para a afirmação da ideia de essência, a qual pode ser traduzida pelo uso da palavra "dom", expressão que encerra a existência feminina na maternidade, no sentido de que toda mulher deve ser mãe, e no espaço privado, mais especificamente no cuidado da família, ou seja, filhos/ as, marido e casa.

No entanto, apesar dessa visível "acomodação" na concepção do que seja ser uma mulher, a realidade não se apresenta de maneira idêntica à ideia de feminino proposta pelas instituições sociais, como a Igreja. É nesse contexto que esses sujeitos, para 
sobreviverem social e financeiramente, vão ter que atuar no espaço público, neste caso, em especial, como professoras.

\section{O que é ser professora?}

As concepções do que é ser professora para esses sujeitos mantêm relações com o que entendem por ser mulher. Em outras palavras, a atuação dessas mulheres no espaço público como educadoras é perpassada também pela maneira como se veem como mulheres no espaço privado.

Desse modo, na definição do que é ser professora, encontramos algumas características semelhantes ao que é ser mulher, como responsabilidade, cuidado, paciência, atenção e carinho:

Bom, ser professora para mim. Olha, é muita paciência, que é extremamente importante na minha profissão né. Compreender a fase que eles estão passando, porque tudo para eles é descoberta, tudo eles estão conhecendo agora né. O que para a gente parece ser natural e bobo, para eles é muito importante né, é muito atrativo. Então, assim, tudo para eles, tudo desperta a atenção, desperta não, eles perdem a atenção nessa faixa. Então, eu tenho sempre que tá voltando nas coisas que eu tô tentando passar, ensinar. E ser professora assim, acima de tudo, eu acho, que sempre passar alguns valores também, para que não isso não se perca né. Nossa sociedade é tão complicada, não somente assim no, no ensino-aprendizagem né, porque eles vão levar para a vida toda, isso para mim é fundamental. (Luísa)

Ser professora é uma responsabilidade muito grande. Eu imaginava uma coisa assim antes de ser professora. Mas, na hora que eu me formei, estou passando por isso, estou praticando, eu vi que é bem diferente assim, que a teoria é bem diferente da prática. Então, tem que estar sempre estudando, sempre é procurando coisas novas pra passar para as crianças, que elas estão, se bobear, um passo à frente da gente. Responsabilidade na hora de dar nota, um conceito para a criança, falar dela para direção ou até mesmo para os pais, elogiar a criança ou não, como falar com essa criança. É, você tem muita responsabilidade tá. (Ana)

É ser responsável pela educação. Acho assim, por uma parte da vida de outras pessoas, uma parte importante da educação, principalmente no começo né da vida delas [crianças], no começo da vida escolar. É ser responsável por elas né, de como elas vão se desenvolver, do que elas vão ser, fazer. (Júlia)

Em primeiro lugar é ter paciência (risos). Porque hoje tá complicado você dar aula porque muitos não querem aprender, muitos não têm vontade. Alguns, os que têm vontade, às vezes não têm estímulo na escola ou na casa mesmo. Eu acho que tem que ter disciplina, o professor tem que ter disciplina, gostar do que faz porque é um sacerdócio, como todo mundo diz, é complicado e tem que ter muita paciência. (Mariana)

Ai eu acho que é ser compreensiva, ser educada né e passar os conhecimentos, os conteúdos de uma forma que integre as crianças. Assim, não fazer uma coisa maçante, de uma forma que as crianças buscam vontade de aprender aquilo, uma forma alegre também. (Michele)

Em contrapartida, duas professoras mencionam a transmissão de conhecimentos no que concerne ser professora, concepção até então racional em comparação ao que foi dito anteriormente pelos outros sujeitos:

Eu, por mais que estejam aí presentes todas as mudanças de deixar um pouco o conteúdo de lado, saber trabalhar projetos, trabalhar aquilo que o aluno sabe, para 
mim, o papel do professor dentro da escola é transmitir sim todos os conteúdos de conhecimento que estão aí para serem ensinados, e que é o conteúdo da série né. Se é conteúdo de $4^{a}$ série, é conteúdo de $4^{a}$ série, não importa se, ah tem, sabe não é assim, eu, eu acho que tem que levar em conta sim o que o aluno sabe. Mas, não ficar só nessa historinha de fazer o que sabe disso e daquilo. Eu acho que tem que ir muito mais além. Eu acho que o papel da professora é transmitir conhecimentos principalmente, e fazer isso de forma que ela consiga chegar em todos os alunos. (Mônica)

Ser professora é conhecer e compartilhar. É, dominar um assunto, um tema, é você conseguir chegar na alma da pessoa e você conseguir que ela mude sua postura ou seu entendimento, que ela rompa dicotomias tão assim inculcadas né, especialmente, entre o senso comum e o saber científico. Uma socializadora de conhecimentos. (Carmem)

No entanto, essas concepções racionais do que é ser professora se diluem quando Mônica, por exemplo, admite que as funções de educadora, de certa forma, fogem da atribuição de transmitir conteúdos, ou então, quando Carmem caracteriza docilidade ao curso de Pedagogia e à professora que trabalha com crianças:

Porque, infelizmente, não é uma carreira bem-sucedida ou é uma carreira difícil de, de você lidar porque como eu falei você não tá, hoje não se liga só com a questão do conhecimento, do ensinar e aprender, mas tem muitas coisas antes para você chegar nisso, da saúde, do físico, do psicológico do aluno, do assistencial. E o professor acaba tendo que dar conta de muitas coisas né. Tem que ser pai e amigo, professor, médico né da criança que tá ali com você. Você é responsável por aquela criança durante o tempo que ela tá com você né. (Mônica)

[...] porque é um curso maravilhoso que te dá tanta dica para ser, de trabalhar com a criança né. É encantador a Pedagogia, é doce, o curso é muito doce, como tem que ser doce a professora que lida com crianças [...]. (Carmem)

Essas falas nos mostram como o conceito de gênero perpassa as concepções do que é ser professora, uma vez que características socialmente atribuídas às mulheres se tornam evidentes na sua atuação docente. É diante dessa perspectiva que Cláudia Pereira Vianna ${ }^{14}$ nos alerta sobre ficarmos atentos/as aos "[...] significados masculinos e femininos que permeiam a história de professores e professoras em suas práticas escolares".

Segundo Vianna, o fato de ser mulher anteceder o de ser professora culmina na definição de estereótipos para a prática docente de homens e mulheres. Desse modo, quando as professoras definem características de responsabilidade, paciência, cuidado, docilidade e carinho como sendo importantes na sua prática escolar, estão, na verdade, definindo estereótipos que atribuem a educação de crianças às mulheres. Além disso, acabam por desvalorizar a profissão docente, já que essa parece uma prolongação do lar e da função de ser mãe. Portanto,

Criam-se, assim, vários estereótipos sobre homens e mulheres: agressivos, militaristas, racionais, para eles; dóceis, relacionais, afetivas, para elas. Em decorrência, funções como alimentação, maternidade, preservação, educação e cuidado com os outros ficam mais identificadas com os corpos e as mentes femininas, ganhando, assim, um lugar inferior na sociedade, quando comparadas às funções tidas como masculinas.

\footnotetext{
${ }^{14}$ Cláudia Pereira VIANNA, 2001-2002, p. 92

${ }^{15}$ VIANNA, 2001-2002, p. 93.
} 
A ideia de sacerdócio invocada por Mariana é outro elemento que justifica a docência como eminentemente um trabalho feminino. Segundo o dicionário Larousse Cultural, ${ }^{16}$ sacerdócio, no sentido proposto por essa professora, nos remete a uma "atividade muito respeitável e que exige grande dedicação e abnegação". Em outras palavras, a ideia de dedicação e de "sacrifício desinteressado", como é indicado o significado para a palavra "abnegação", 17 assemelha-se em muito à atividade maternal e à ideia de vocação, que, por sua vez, reporta a algo inato. Consequentemente, temos mais um fator que deprecia a docência em relação a outras profissões. Assim, como argumentam Cristina Bruschini e Tina Amado,

Com tão poucas vantagens, em suma, como se explica que o magistério ainda seja visto como sacerdócio ou vocação? Provavelmente porque a ideologia da vocação, do amor e da dedicação tem justamente por função encobrir as condições concretas em que se dão as relações de trabalho. ${ }^{18}$

Outra circunstância que ratifica o ser mulher ao ser professora é o fato de algumas dessas educadoras se verem como modelos para seus/suas alunos/as:

[...] eu fiquei pensando sobre isso, como o professor é um espelho. As crianças chegam na escola, ainda mais em escolas periféricas, como a que eu trabalho, são muito carentes, eles não têm orientação em casa, nem um tipo assim, comportamento, disciplina, nada, eles são livres [...]. Então, eu enfrento problemas com alunos indisciplinados, e "Por que isso?". Então, o professor tem muita responsabilidade também nisso, na formação do caráter das crianças, de dar o exemplo, uma palavra que você fala para a criança pode destruir tudo o que você já construiu com ela [...]. (Ana)

[...] eu acho assim, ensinar é uma coisa de ter responsabilidade. Você ensina direito, ele aprende direito, você não faz bem, aquele aluno não vai ser, você vai, de certa forma, prejudicar, tá prejudicando ele. Então, eu acho que é, ter um, por isso você tem que ser responsável, você tem que ter o cuidado de como você vai fazer, de você fazer bem o seu serviço porque ali é uma pessoa né que você tá lidando [...]. (Júlia)

Essas falas indicam que o/a professor/a é uma referência para o/a aluno/a, portanto pode ser imitado/a. Porém, no caso da educação infantil e fundamental, parece que exercer a profissão docente se torna algo ainda mais sério e delicado, uma vez que, geralmente, a educação desses níveis é atribuída às mulheres e, sendo assim, essas devem apresentar uma conduta ainda mais condizente ao que é moralmente proposto pela sociedade em relação ao seu gênero.

Segundo Guacira Lopes Louro, ${ }^{19}$ é com a feminização do magistério no fim do século XIX e início do século XX que educar crianças na escola vai ser associado à maternidade, ou seja, como a mulher biologicamente pode dar à luz, subentende-se também que pode ser o melhor sujeito no cuidado de crianças. Além disso, como enfatiza Louro, tal prerrogativa vai legitimar o abandono da docência pelos homens, que, a partir do século XX, vão partir para profissões que possibilitam ascensão econômica. É nesse contexto que

Afirmavam que as mulheres tinham, "por natureza", uma inclinação para o trato com as crianças, que elas eram as primeiras e 'naturais educadoras', portanto nada mais adequado do que lhes confiar a educação escolar dos pequenos. Se o destino primordial

\footnotetext{
${ }^{16}$ LOVISOLO, 1992, p. 1003.

17 LOVISOLO, 1992.

${ }^{18}$ Cristina BRUSCHINI e Tina AMADO, 1988, p. 7.

19 LOURO, 2001.
} 
da mulher era a maternidade, bastaria pensar que o magistério representava, de certa forma, "a extensão da maternidade", cada aluno ou aluna vistos como um filho ou filha 'espiritual'. O argumento parecia perfeito: a docência não subverteria a função feminina fundamental, ao contrário, poderia ampliá-la ou sublimá-la. Para tanto seria importante que o magistério fosse também representado como uma atividade de amor, de entrega e doação. A ele acorreriam aquelas que tivessem "vocação". ${ }^{20}$

Outro fator que evidencia a correspondência entre o ser mulher e o ser professora consiste nas influências que essas educadoras receberam para escolher a profissão docente. Em sua maior parte, a escolha por ser professora advém da admiração, ou então, do conselho de uma mulher que teve papel importante na vida desses sujeitos:

Eu sempre me lembro da minha primeira professora né. O jeito dela, assim, o jeito dela ensinar, o jeito dela com as crianças, então constantemente eu, eu penso nela [...]. Muito carinhosa, muito atenciosa [a professora]. Então, eu acho que foi a professora que mais me marcou assim. E eu lembro é do jeito dela explicar as coisas pros alunos né, o jeito de brincar. (Luísa)

Mas, eu me lembro bem que eu me apaixonei pela minha professora lda préescola), pelo carinho que ela tinha, pela vontade de ensinar. Eu tinha muita vontade de aprender. Então, eu lembro que antes dela eu queria aí ser dentista, eu queria ser médica, mas na hora que eu vi a professora lecionando, dando aula, é isso que queria ser, era isso. Tanto que fui várias vezes ann, ela tomava como exemplo, mandava ensinar na lousa. Então, tudo o que eu ouvia da professora eu queria aprender bem para poder ensinar os outros porque eu sabia que eu ia ser professora. Então, tudo, ann minha memória assim, sempre foi ótima porque eu ouvia para poder passar. Então, eu tinha que aprender para poder ensinar quando, quando eu fosse professora. (Ana)

Bom, quando, quando eu saí da, porque eu fiz cursinho, não passei pela última vez, a minha mãe, ela falou para mim "Vai fazer magistério". Mas, eu fui assim, eu fui por ir porque eu "Ai meu Deus, será que eu vou gostar disso?". Não sei, pensava né. Mas, eu gostei, acabei gostando. Foi uma experiência muito boa para mim. (Mariana)

Na minha família, acho que tem uns dez, umas dez professoras, eu tenho umas duas tias, três, umas cinco primas de segundo grau. Mas, assim quando eu era um pouco menor eu tinha contato com as tias que eram mais próximas. Então, eu via o trabalho e tudo. Mas, não sei, eu me lembro que desde pequena eu brincava de escolinha, dessas coisas, sempre gostei. Eu acho que a imagem que eu via né só me fazia gostar mais [...]. (Michele)

Podemos observar nos discursos dessas mulheres a admiração por suas professoras e as influências da família, mais especificamente das mães, tias e primas, na escolha da profissão docente.

O entrecruzamento do ser professora com o ser mulher também pode ser notado na fala de Mônica, mas no sentido de que a profissão docente pode permitir a conciliação entre o espaço público, dar aulas, e o espaço privado, ou seja, o trabalho que deve desenvolver no lar:

[...] eu vejo positivo de ser professor. Assim, ao mesmo tempo em que eu acho positivo, eu acho eu não deveria ser assim. Mas, a questão de poder trabalhar meio período, eu não quero trabalhar os dois períodos porque eu quero ter um período para cuidar da minha casa e para quando eu tiver meus filhos, poder cuidar deles. (Mônica)

${ }^{20}$ LOURO, 2001, p. 450. 
Assim, por mais que Mônica saiba como é sacrificante a dupla jornada, trabalho na escola e trabalho em casa, pois afirma que "não deveria ser assim", acaba concordando no final com a ideia de que

De fato, a possibilidade de impor o próprio ritmo e uma certa flexibilidade de horários permite à mulher conciliar os papéis de dona-de-casa e educadora. Rosemberg (1982) lembra que as escolhas femininas são sempre movidas por um forte senso de realidade ou "sabedoria da conciliação", que leva as mulheres a escolher carreiras mais flexíveis, sabendo de antemão que não encontrarão apoio ou ajuda para as tarefas domésticas, o magistério seria então especialmente atraente para aquelas com responsabilidades familiares.

A frase de Mônica "não deveria ser assim" nos indica que, apesar da acomodação dessas educadoras na relação que a carreira docente estabelece com as características socialmente atribuídas às mulheres, há certa resistência na aceitação dessa ideia, já que essa afirmação vem questionar por que a mulher, além de trabalhar no espaço público, tem que também ser responsável pelo cuidado do lar, do marido e dos/as filhos/as.

O questionamento dessa professora é interessante porque mostra a dialética do processo de acomodação e resistência ${ }^{22}$ em se tornar uma mulher, uma vez que evidencia os conflitos de aceitação e rejeição da feminilidade. Desse modo, como Mônica, algumas professoras também passam por esse conflito, pois o que lhes é destinado socialmente para ser uma mulher nem sempre corresponde ao que vivem cotidianamente:

Então, eu acho assim que até por isso eu nunca toquei no assunto de casar, de me casar, porque eu tenho certeza assim, se eu sair de casa, o meu dinheiro vai fazer falta para eles [a família] né. (Luísa)

Porque é muito tempo né que você tem, que você tenha, que você tem obrigações, tem valores para cumprir né. Ninguém é na integra a pessoa que é. Você sempre vai dever uma obrigação a alguém, uma satisfação a alguém, você sempre tem um valor para dirigir sua vida, não existe "Eu sou eu e acabou". Mentira, uma grande, uma falácia essa. Eu procuro ser, eu sou mais eu, mas eu acho que é impossível ser só eu. (Carmem)

Nas falas de Luísa e Carmem, observamos a construção social do feminino e a aceitação e resistência para ser tornar uma mulher. Notamos que, no caso de Luísa, há a aceitação de um sonho, geralmente feminino, ou seja, de casar-se. No entanto, sua função de provedora da família faz com que esse sujeito resista à realização desse sonho. Já Carmem revela resistências, pois admite que, muitas vezes, desempenhamos papéis, e aí podemos incluir o papel de ser uma mulher, para sobreviver em sociedade.

Esses relatos nos mostram, portanto, que a concepção de ser professora é perpassada pela maneira como essas educadoras se entendem como mulheres. É nessa perspectiva que, em alguns momentos, desempenham o papel de mãe, ou melhor, de "tia" de seus/ suas alunos/as. No entanto, não são meras receptoras das imposições de feminilidade propostas pela sociedade, o que as faz questionar algumas regras impostas para o ser mulher e para o ser professora.

\section{O que são relações de gênero?}

Para complementar nosso entendimento de como essas professoras se entendem como mulheres e profissionais da educação, interrogamos essas educadoras sobre o que

\footnotetext{
${ }^{21}$ BRUSCHINI e AMADO, 1988, p. 7.
} 
consideram relações de gênero. Sob essa perspectiva, observamos que o gênero, na concepção dessas mulheres, assume um caráter eminentemente heterossexual:

[...] é o tratamento diferenciado entre homem e mulher. Que eu sinto que isso existe bastante em relação ao trabalho, em relação ao sexo mesmo né, porque o homem sempre pode, pro homem tudo permitido e para a mulher não, é em relação a salário, em relação à posição social. Eu acho que é tudo isso. (Luísa)

Tá. Homem e mulher. Pra mim é o, ao falar que é, é não vou falar que é o normal, que as outras pessoas são normais também, mas é o que, foi, foi instituído para homem e mulher. (Ana)

[...] acho que todo tipo de relação que acontece entre assim entre gênero, homem e mulher, essas diferenças, acho que é isso (risos). (Júlia)

[...] relações de gênero são comportamentos, que eu falei, meninos e meninas. É meio estranho porque menino pode tudo, menina não pode nada, e mulher e homem fica meio estranho né. Mas, não é que menino pode tudo, mas menino, sei lá, não sei (risos) como falar para você (risos). Como que a gente vai educar igual, menino e menina né? Porque fala menino vai ficar mais afeminado, não tem essa também. Eu acho, sei lá, tem que ser, vai educar igual, mas como? (Mariana)

Relações de gênero? Relações de homens e mulher relacionados assim. Como eu vou te explicar? [...] Ao que é ser homem e ao que ser mulher e o que está implicado com isso, os papéis, o imaginário, as imagens do que é ser homem e do que é ser mulher. (Mônica)

É a diferença, e viva a diferença! Seria o complemento, uma necessidade, uma união, o equilíbrio, o equilíbrio. É como yin e yang né. Eu acho que é uma figura que representa muito bem a questão do gênero, o quente e o frio, o seco e o molhado, o ódio e o amor né. Eu vejo a questão de gênero como assim, os opostos, a necessidade dos opostos, dos pesos, dos dois lados para se ter o equilíbrio. (Carmem).

Relacionamentos entre homens e mulheres? É isso que me vem na cabeça, relações de gênero, relações entre homens e mulheres né, em vários campos. (Michele)

Os discursos dessas professoras evidenciam que o gênero está centrado na matriz heterossexual, referindo-se a atitudes, comportamentos e condutas referentes ao sujeito que se constitui como homem ou como mulher. Verificamos, desse modo, a rigidez que o conceito de gênero assume na perspectiva dessas professoras, já que "as estruturas hierárquicas repousam sobre percepções generalizadas da relação pretensamente natural entre masculino e feminino". ${ }^{23}$

Em outras palavras, por mais que, em seguida, admitam o caráter cultural do gênero, no sentido de que esse conceito permite-nos enxergar as diferenças que socialmente são atribuídas a homens e mulheres, o fato de fixá-lo no que é determinado ao masculino e ao feminino, sem considerar outras configurações que o gênero possa assumir, recai novamente na ênfase no aspecto biológico.

De fato, a concepção do gênero somente como heterossexual assemelha-se à ideia que o feminismo dos anos 1960 alavancava, ou seja, de que o sexo constitui a matriz para as diferenças sociais entre homens e mulheres. Nesse entendimento do conceito de gênero, como explica Linda Nicholson, "[...] o biológico foi assumido com base sobre a qual os significados culturais são construídos. Assim, no momento mesmo em que a influência do

\footnotetext{
${ }^{22}$ ANYON, 1990.

${ }^{23}$ SCOT, 1995, p. 18.
} 
biológico está sendo minada, está também sendo invocada". ${ }^{24}$ No entanto, devemos considerar que a própria ideia de sexo como constituinte das diferenças biológicas entre os gêneros é socialmente construída. ${ }^{25}$

A ideia de que o sexo determina o gênero não permite, por exemplo, que Ana e Carmem vejam a homossexualidade como uma forma diferente da heterossexualidade de orientação para os desejos e os prazeres sexuais:

Vou falar para você que eu não aceito a homossexualidade, eu acho estranho, mas eu convivo com pessoas normalmente, tá. Então relações de gênero para mim seria relações de feminino e masculino, homem e mulher [...]. É porque não foi uma coisa que foi criada por Deus, instituído por Deus. É, eu acredito na criação dEle, por eu acreditar na Bíblia, sigo os princípios dela e isso daí não foi criação dEle, a gente vê que foi criação humana [...]. (Ana)

Eu acredito que são pessoas infelizes porque diante da nossa sociedade que não aceita. Eu acho que por mais que eles riem, se mostrem alegres eles são extremamente infelizes porque eles têm amores proibidos, alguns reprimidos. Eles, alguns, mesmo que até não correspondidos, por isso que eu acho infelizes, em matéria de sentimentos deles. Eu penso no coração deles, não penso no ato sexual porque o ato sexual em si ele não tem propósito, o ato sexual homossexual, entre iguais, não tem um propósito. Mas, eu acho que vai além, essas pessoas têm um sentimento e na parte de sentimento eu vejo, sinto infelicidade. Por isso, que eu te falei de amor não correspondido, proibido, reprimido [...]. Não tem propósito, uma relação sexual entre homens, você vai ter um pênis com sexo anal, o propósito eu estou falando de reprodução né. Porque quando o homem ejacula, você tem os espermatozoides, eles vão fazer o quê dentro de um intestino? Esse, não tem um propósito de gerar vida. (Carmem)

A fala dessas professoras, além de indicar um caráter heterossexual ao gênero, também admite a esse conceito a função de reprodução biológica, uma vez que a relação entre um homem e uma mulher tem como finalidade gerar vidas, o que na relação homossexual torna-se impossível. Tais discursos são impregnados de religiosidade, apesar de que Carmem, diferentemente de Ana, não faz menção a nenhuma religião.

Todos esses discursos sobre relações de gênero e sexualidade nos levam a observar como essas instâncias ainda encontram respaldo nas diferenças biológicas, o que faz com que essas mulheres admitam características inatas ao sujeito masculino e ao sujeito feminino, como também uma só possibilidade de viver os desejos e as práticas sexuais, ou seja, a heterossexual. Tal prerrogativa ainda subsidia a maneira como se entendem como mulheres e profissionais da educação, no sentido de que suas condutas, tanto no espaço público como no privado, devem corresponder ao que é socialmente estipulado ao seu gênero.

Verificamos, portanto, que, em um processo de "acomodação" e "resistência", as categorias "mulher" e "professora" se fundem. Tal associação "obscurece", em certa medida, a atuação da professora como profissional da educação, uma vez que seu papel de educadora vai se mesclando com o de "segunda mãe" de seus/suas alunos/as.

\section{Referências bibliográficas}

ANYON, Jean. "Interseções de gênero e classe: acomodações e resistência de mulheres e meninas às ideologias de papéis sexuais". Cadernos de Pesquisa, São Paulo, n. 73, p. 13-25, maio 1990.

\footnotetext{
${ }^{24}$ Linda NICHOLSON, 2000, p. 11.

${ }^{25}$ BUTLER, 1987.
} 
BARDIN, Laurence. Análise de conteúdo. Lisboa: Edições 70, 1977.

BRASIL. Ministério da Educação. Secretaria de Educação Fundamental. Parâmetros Curriculares Nacionais: pluralidade cultural/orientação sexual. Rio de Janeiro: DP\&A, 2000.

BRUSCHINI, Cristina; AMADO, Tina. "Estudos sobre mulher e educação: algumas questões sobre o magistério". Cadernos de Pesquisa, São Paulo, n. 64, p. 4-13, fev. 1988.

BUTLER, Judith. "Variações sobre sexo e gênero: Beauvoir, Witting e Foucault". In: BENHABIB, Seyla; CORNELL, Drucilla (Org.). Feminismo como critica da modernidade. Tradução de Nathanael da Costa Caixeiro. Rio de Janeiro: Rosa dos Tempos, 1987. p. 139-154.

CARVALHO, Maria Eulina Pessoa de; PEREIRA, Maria Zuleide da Costa (Org.). Gênero e educação: múltiplas faces. João Pessoa: UFPB, 2003.

CERVO, Amado Luiz; BERVIAN, Pedro Alcino. Metodologia científica. 4. ed. São Paulo: Makron Books, 1996.

FOUCAULT, Michel. História da sexualidade l: a vontade de saber. Tradução de Maria Thereza da Costa Albuquerque e J. A Guilhon Albuquerque. 10. ed. Rio de Janeiro: Graal, 1988.

LOURO, Guacira Lopes. Gênero, sexualidade e educação: uma perspectiva pósestruturalista. Petrópolis: Vozes, 1997.

"Mulheres na sala de aula". In: DEL PRIORE, Mary (Org.). História das mulheres no Brasil. 5. ed. São Paulo: Contexto, 2001. p. 443-481.

Gênero, sexualidade e educação: uma perspectiva pós-estruturalista. Rio de Janeiro: Vozes, 2003.

LOVISOLO, Elena (Ed.). Larousse Cultural: dicionário de língua portuguesa. São Paulo: Nova Cultural, 1992.

NICHOLSON, Linda. "Interpretando o gênero". Revista Estudos Feministas, Florianópolis, v. 8, n. 2, p. 9-41, ago./dez. 2000.

RIBEIRO, Paula Regina Costa. Inscrevendo a sexualidade: discursos e práticas de professoras das séries iniciais do Ensino Fundamental. 2003. 113 f. Tese (Doutorado em Ciências Biológicas: Bioquímica) - Instituto de Ciências Básicas da Saúde, Universidade Federal do Rio Grande do Sul, Porto Alegre, 2003.

. "Professora, minha mãe e meu pai não trabalham. Por que ele é desempregado e ela é do lar? Discutindo as relações de gênero nos espaços educativos". In: SOUZA, Cláudio Benedito Gomide de; RIBEIRO, Paulo Rennes Marçal (Org.). Desafios educacionais para o séxulo XXI: contribuições dos contextos espanhol e brasileiro. Araraquara: Laboratório Editorial da FCL-Unesp, 2010. p. 85-103.

RIBEIRO, Paulo Rennes Marçal. Educação sexual além da informação. São Paulo: EPU, 1990.

SCOTT, Joan. "Gênero: uma categoria útil de análise histórica". Educação e Realidade, Porto Alegre, v. 20, n. 2, p. 5-19, jul./dez. 1995.

VIANNA, Cláudia Pereira. "O sexo e o gênero da docência". Cadernos Pagu, Campinas, n. 17-18, p. 81-103, 2001-2002.

[Recebido em 15 de março de 2011

e aceito para publicação em 10 de maio de 2011] 
Teachers or Women: An Analysis of the Concepts of Gender and Sexuality Among a Group of Pedagogy Students

Abstract: This study aims to investigate the concepts of gender of a group of students from the Faculty of Education, who already work as teachers in schools. For this research, a qualitative and analytic-descriptive typology, we used a semi-structured interview with the students. The construction and analysis of the object were based on theoretical studies of Michel Foucault, Joan Scott and Guacira Lopes Louro. We found that these teachers lack a training in theories and discussions focusing on sexuality and gender issues.

Key Words: Sexuality; Gender Relations; Pedagogy Course. 